\title{
İktidar İlişkilerine İndirgenmiş Babalık İmajı ve Postyapısalcı Otorite Analizinin Çelişkileri ${ }^{1}$
}

\author{
Ömer Say
}

İstanbul Medeniyet Üniversitesi, Edebiyat Fakültesi, Sosyoloji Bölümü, İstanbul.

\section{Öz}

İnsanlık tarihi boyunca toplumların büyük çoğunluğunda aile içindeki otorite, babanın merkezi konumu etrafinda şekillenmiştir. Bu otorite, kültürel ve yapısal farkllikklara göre çeşitli toplumlarda değişik görünümler ortaya koymuştur. Öte yandan geleneksel toplumlardaki iktidar ilişkileri ile aile içindeki yapı arasında kimi zaman benzerliklere rastlanmıştır. Tarihsel süreçte Roma Imparatorluğu Batı tipi iktidar ilişkileri ve babalık otoritesi için önem arz eder. Yeni Çă̆'dan itibaren kapitalizme özgü yapı, babanın otoritesi de dâhil olmak üzere tüm otoriteleri kendinde toplamıştır. Bu aynı zamanda her alanda merkezileşme olarak da adlandırılmaktadır. Ancak 20. yüzylla birlikte gittikçe artan oranda iktidara ilişkin yapı, yapısalcular ve postyapısalcılar tarafından eleştirilmiştir. Özellikle postyapısalcı eleştiriler ve öne sürdükleri savlar günümüzde dikkat çekmektedir.

Anahtar Kelimeler: İktidar İlişkileri, Babalık Otoritesi, Postyapısalcılık.

\section{The Image of Fatherhood Reduced Power Relations and Contradictions of Poststructuralist Analysis of the Authority}

\begin{abstract}
Authority of political power and dominance of father in families differ greatly through the human history in all societies. In western societies Rome civilization onwards the link between power relations and dominance of father has been important. At the beginning of new age a new kind of structure has been started in power relations and dominance of father under the control of capitalist system. This new kind of system started to aggregate all kind of authorities and powers in its system. It is also called centralization. But during the 20th century both centralized power and dominance of father were started to be criticized. The fact that there is a concept of authority at the center of criticism. Among all the criticisms, especially opinion of poststructuralist thinkers are taken into consideration in our time.
\end{abstract}

Keywords: Power Relations, Fatherhood, Poststructuralism.

\section{GİRiş}

Tarihin yazıya dökülebilmiş gelişimi içinde dünyanın büyük bölümünde erkek egemen toplum tipinin ağır basmış olduğu görülür. Erkek egemen ifadesi akla ilk anda bir ailede en başta baba olmak üzere erkeklerin kadınlardan daha üstün tutulduğu aile tipini getirmektedir. Bununla birlikte egemenlik kavramı başlı başına yöneten ve yönetilen ilişkisi içinde anlaşılacak bir anlama sahiptir. Bu durumda erkek egemenliği dendiğinde siyasal ilişkilerin akışından, toplumsal yaşamın çerçevesine kadar

\footnotetext{
${ }^{1}$ Bu makale, "Değişen Dünyada Yeni Erkek Kimliği; Ailevi ve Toplumsal Sorunlar Sempozyumu”nda sunulan “Erkeklik Kavramı ve Tarihsel Değişimi” adlı tebliğin değiştirilmiş ve geliştirilmiş şeklidir.
} 
etkileyici olan bir yaşam biçiminin kastı gerçekte kavramın doğru kullanımının bir gereğidir.

Modern devletlerin aidiyet ve otoriteyi sağlamlaştırmak istediğinde geleneksel baba imajını kullanmayı tercih ettiklerine sıklıkla vurgu yapılmaktadır. Sözgelimi Latin Amerika devletleri için kullanılan babalık imajının bir simge olduğunun söylenmesi böyle bir amacı göstermektedir. Onlara atfen söylenen şu cümleler bu gerçekliği yeterince açılamaktadır: "Bağımsızlık sonrası Latin Amerika'da kurulan ve günümüze değin süregelen devlet yapılarının ortak özelliği ‘Bürokratik-Otoriter Cumhuriyet' oluşlarıdır. Bu modelin en belirgin vasfı, devletin, -ister sivil, ister asker egemenliğinde olsun- kendisini, halkı kolonyal güçlerden kurtaran bir baba olarak görmesidir" (Öke, 2010: 92).

Aslında bu tür yaklaşımlarda aile, toplumsal yapının tam merkezine yerleştirilmekte ve onun bir prototipi gibi resmedilmektedir. Bu durum, ailenin üzerine aileye ait olmayan bir sorumluluğun yüklenmesini doğurmaktadır. Ancak daha da önemlisi aile ve iktidar ilişkileri arasında kurulan bağ nedeniyle aile, gerçek anlamının dışında tutulmaya ya da en geniş açılı haliyle anlamlarından sadece birine ait bir soyutlamanın içine sıkıştırılmaktadır. Böylece birinci adımda babalık sadece otoriteye indirgenmekte ve bu indirgemeye dayanarak yeniden iktidar ilişkilerine dönülmekte ve iktidarın da yalnızca bir otorite olarak sunumu sağlanmaktadır.

Babalık otoritesi bir otorite biçimi olmakla birlikte salt yöneten yönetilen ilişkisine indirgenemeyecek karmaşık bir sosyal ilişkiler bütünlüğünün birleşimidir. Her şeyden önce baba, somut olarak mevcuttur ve bütün soyut duygu durumlarla birlikte bir varlıktır. Bu çerçevede geçmişten günümüze aile içindeki babalık otoritesine ait değişim ile 20. yüzyılda gittikçe artan iktidar eleştirileri ile bu eleştirilerin aile kurumundaki değişimle gösterdiği paralelliklere işaret edilecektir. Diğer taraftan özellikle postyapısalcı iktidar eleştirilerinin çelişkileri üzerinden sorunun temeline inilmeye çalışılacaktır.

\section{Geleneksel Toplumlar ve Babalık Otoritesi}

Tarihte Mezopotamya bölgesinde hem Sümer hem de Babil devletlerinde birbirlerinden çok farklılaşmayan baba imajı ve otoritesine şahit olunmaktadır. Babanın otoritesi de temelde erkeklerin toplumsal kurallar açısından daha belirleyici konumda olmalarına dayanmaktadır. Bununla birlikte erkekler arasında da baba olmak ayrı bir statünün varlığını ortaya koymaktadır. Büyük bir aile içinde en yaşlı baba en yüksek otoriteyi temsil etmektedir. Oğullardan evli ve baba statüsünde olan kişinin, en büyük baba karşısındaki yeri genel anlamda itaat ve saygı boyutunda kalmaktadir.

Bu en eski sistem içinde ailenin bütünlüğü baba ve onun yokluğu halinde ise en büyük oğul olan halefi ile temsil edilmektedir. En büyük oğul daima en ayrıcalıklı olandır ve baba malında hak sahibidir. Zira erkek evlatların statüleri onların yaşça büyüklüklerine göre şekillenmektedir. Erkek çocuğun yokluğu durumunda ise kız evlat, erkek evladın sahip olabildiği hukuki haklara kavuşmaktadır (Yalvaç, 1965: 31- 
32). Kadının yerinin ancak erkekten sonra oluşabilmesinden dolayı kural olarak, baba veya erkek kardeş yoksa çocuklar üzerindeki velayet hakkı anneye geçmektedir. Kız çocukları arasından evlenmemiş olanlar mal paylaşımında erkek kardeşleri ile birlikte varis olarak kabul edilmektedir (Demir, 2012: 37).

Görünen o ki aile içinde en yüksek otoriteyi oluşturan babadan sonra, hiyerarşi en büyügüunden başlayarak erkek kardeşler, ardından anne ve en sonunda da kız evlat ile sağlanmaktadır. Evlenmiş kızın kocası, yani damat ise aile dışından bir yabancı statüsünü işgal ettiği gibi erkek egemenliğin toplumsal kabulünden dolayı kız evladı da aileye yabancılaştırmakta ve onun mirastan mahrum olmasına neden olmaktadır. Ancak yine de kız evlatla evlenmiş olan damat her koşulda bir yabancı değildir. Damadın da evlat olarak kabul edilebildiği durumlar mevcuttur.

Damadın aile içinde benimsenmesi ve evlat olarak kabul edilebilmesinde birinci şart evde erkek evladın olmamasıdır. Böyle bir hal içinde yabancı erkeğin, evlenme yoluyla aileye girmesi ve kayınpederine saygı ve itaat içinde olması gerekmektedir. Saygı ve itaatin yerine getirilmesi damadın kızdan daha önemli bir konumda tutulmasını sağlayabilmektedir. Çünkü eğer kayınpeder onu evlat gibi gördüğü takdirde damat, ailenin varisi haline gelmektedir. Evlilik ancak bu şartlarda kocanın lehine olarak işlemekte ve ailenin her şeyini damat elde etmektedir. Aksi durum vuku bulduğunda damadın hakkı ortadan kalkmaktadır (Yalvaç, 1965: 32).

Babaya itaatin ne düzeyde olduğu onun otoritesinin reddedilmiş olduğu durumlarda açığa çıkmaktadır. Çünkü babasını reddeden bir çocuk, tıraş edildikten sonra köle olarak satılabilmektedir. Dolayısıyla bedeli oldukça ağırdır (Bozkurt, 1981: 70). Babil devletinde de babaya karşı gelen çocuk şiddetle cezalandırılmaktadır. Mesela Babil hükümdarı Hammurabi'nin hazırlamış olduğu kanunlara göre babasını döven bir çocuğun eli kesilmektedir (Demir, 2012: 38). Sadece aile ilişkileri bağlamında değil daha geniş bir toplumsal ilişkiler sisteminde değerlendirildiğinde görülür ki babaya karşı gelmek ya da onu reddetmek, ilkin ceza almayı, ikinci olarak yabancı sayılmayı ve üçüncü olarak da en aşağı seviyede bir sınıfa ait olmayı göze almak demektir. Babasını reddeden kişi, sadece aileden değil toplumdan da dışlanmaktadır. Bu durum, babanın mutlak hâkimiyetinin toplum içindeki kabulünü açıkça ortaya koyar.

Mezopotamya dışındaki Doğu toplumlarında da derece farklılıklarına rağmen babanın aile içindeki yüksek otoritesine şahit olunmaktadır. Hindistan'dan Çin'e ve İran'a kadar bilinen birçok eski uygarlıkta aile içindeki otorite babaya aittir. Yalnız, Brahmanlarda, babanın erkek çocukları üzerindeki velayet hakkı, bu çocukların dini bir görev ifa etmeleri halinde sona ermektedir. Çin'de otorite sahibi olarak baba, gerek gördüğünde çocuklarını satabilmektedir. Her ne kadar satma konusunda çocuğun rızası aransa da eğer aile fakirlik yaşıyorsa satarken çocuğun rızasına başvurmaya gerek kalmayabilmektedir. Babanın ölümü sonrasında ise ailenin velayet hakkı en büyük erkek çocuğa geçmektedir. Yine eski İran hukukuna göre de kadın ve çocukların babaya karşı mutlak itaat görevleri vardır. Yahudilerde de babanın çocuklar üzerinde bir hâkimiyet sahibi olduğu açıça görülmektedir. Baba ve annesini döven, onlara hakaret eden çocuklar ölüm cezasına çarptırılabilmektedirler (Demir, 2012: 38-40). 
Eski Türklerde babaya itaat bulunmakla birlikte sınırsız değildir. Töre babanın da üstünde tutulmaktadır. Toplumda babaya ve oğula düşen görevler birbirlerinden ayrılarak değerlendirilmektedir. Meselâ baba oğlunu evlendirmek zorundadır. Eğer baba bu görevini yerine getirmez ise oğul babasından zorla masraflarını alabilmektedir. Fakat aynı zamanda oğlan evlendikten sonra babasının izni olmadan evinden ayrılamamaktadır (Aksoy, 2011: 13). Dolayısıyla babanın sorumlu olduğu konularda sınırını aşmak gibi bir kayıtsız otorite sahibi olmasına izin verilmemiştir. Bir yandan babaya bir otorite verilirken bir yandan da göçebe şartlarında aile birlikteliğinin korunmasına yönelik törenin hâkimiyeti görülmektedir.

Osmanlı toplumunda da çocuğun, babanın hukukî denetimi altında olmasıyla devam etmiştir. Kayıtlar kız ve erkek çocuğun baba çizgisinde bir aidiyet içinde doğduğunu gösterir (Aksoy, 2011: 16). Bu çerçevede Türk toplumunda aile yapısına ilişkin çok geniş ölçekli bir değişmenin yaşanmadığı ortaya çıkmaktadır. Dahası eski Mezopotamya uygarlı̆̆ından beri birçok Doğulu toplumda ailenin yapısına ilişkin önemli bir değişmenin yaşanmadığ 1 görülmektedir. Bu ailedeki değişimin çok da hızlı olmadığını göstermektedir.

Her şeye rağmen ortaya çıkan yavaş değişmenin zaman ilerledikçe sadece babanın otoritesinin daha esnek bir yapıya dönüştüğü şeklinde özetlenebilir. Değişmenin seyri ise şu şekilde özetlenebilir: Sümer ve Babil devletlerinde baba otoritesi çok daha baskın bir düzeyde seyrederken özellikle semavi dinlerin toplumlar tarafından kabulü sonrasında mutlak otorite baba yerine dinin kuralları olarak belirmektedir. Eski Türklerdeki törenin babanın otoritesini sınırlama yetkisi de bunu ortaya koyar.

Kendi gelenekselliği içinde Doğu toplumları belli özelliklerini günümüze taşımış olsa da çağdaş Batı uygarlığının dünya üzerindeki etkisi nedeniyle hemen hemen tüm toplumların aile yapısında değişmeler meydana geldiği ayrıca gözlenmektedir. Bir başına modern eğitimle gelen değişim sonucunda ortaya çıkan yeni toplumsal ilişkiler ve yaşam tarzları bu gerçeği açıkça ortaya koyar. Ancak çağdaş Batı uygarlığının sadece Batı dışı toplumlara etki ederek onlarda değişmeye yol açtığı tezi eksik bir iddiadır. Zira bizzat Batılı toplularda da geleneksel yapıda meydana gelen değişimin oldukça önemli düzeyde yaşandığı gözlenmektedir. Bu açıdan mevcut Batı kültüründeki babanın yeri salt geçmiş Batı uygarlıklarına ait bir vasfı içermemektedir.

Modern Batı düşüncesinin gelişim temellerinde Yunan ve Roma uygarlığ bulunmakla birlikte devlete ilişkin kurumlaşmalarda ve örgütlenmelerde Roma uygarlığının etkilerini daha baskın olarak görürüz. Aileye ilişkin yapıda otoritelerinde farklılık bulunmakla birlikte merkezi konum her iki uygarlıkta da babaya aittir. Roma'da babanın merkezi otoritesi altındaki ailede babanın dışında evin hanımı, çocukları ve köleleri yer almaktadır. Roma uygarlığının ilk dönemlerinde babası henüz hayatta olan bir erkek evlat, kendisi baba olsa dahi aile reisi sayılmadığı için aile reisliği tıpkı Mezopotamya'daki gibi sağ olan en büyük babayı işaret etmektedir. Ancak aile reisliğine ait otoritenin, Roma'da tüm Doğu toplumlarınkinden çok daha 
baskın olarak işlediği görülmektedir. Bu otorite babanın her anlamda evlat üzerindeki mutlak hâkimiyetini kapsayacak türdendir. Sözgelimi aile reisi, çocuklar üzerinde ölüm dirim hakkını da haizdir. Onun rızası olmadan aile bireylerinin evlenmeleri de imkânsızdır (Berki, 1957: 114; Demir, 2012: 42).

Bununla birlikte erken Roma'da aile reisinin sahip olduğu haklar Roma hukukunun tarihi serüveni içinde çeşitli değişikliklere uğramıştır. Çocuğunu gizlice öldüren baba cezalandırılmaya başlanmış, kötü muameleye maruz kaldığında evladın özgürleşmesi sağlanmıştır. Gelişim çizgisi içinde evladın hayatı ile ilgili cezalar için önce izin şartı konmuş, imparatorluk devrinde de kanunlar yapılmıştır. Ayrıca çocuğun terk edilebilmesine rağmen akrabalık bağının reddedilememesi de sağlanmıştır. Aynı zamanda artık baba, çocuklarının evliliklerine keyfi olarak müdahale edemez duruma gelmiştir. Dahası bir aile ferdini bile bile satın alan kişi de cezaya çarptırılmaya başlanmıştır. Bütün bu gelişmeler M.S. 3.yüzyıla kadar geçen sürede genel itibarla tamamlanmış oluyordu (Berki, 1957: 114-115).

Roma devletinde ortaya çıkan siyasal ve toplumsal kurumlaşma biçimleri Batı tarihinde modern cumhuriyetlerle yeni örgütlenme biçimlerine dönüşmüştür. Modernizm, devlet düşüncesinde Roma Cumhuriyeti'nin kurumsal özelliklerini ve Yunan felsefesinin düşünsel yapısını önemli ölçüde kendi birikimine katmıştır. Bu yüzden de modern dönem üzerinden günümüze etki eden kurumsal yapılara karşı geliştirilen postyapısalcı eleştiriler aynı zamanda Roma'nın siyasal örgütlenme yapısına ve özellikle Sokrates sonrası Yunan felsefesine karşı duran bir eleştiri biçimini ifade etmektedir.

Antik Yunan site devletlerinde de Roma'daki gibi babanın konumu, bir çok konuda aile bireylerinin hak ve hürriyetlerini otoritesi içine almış olarak belirir. Baba, çocuklarını cezalandırma ve hatta satabilme hakkına sahiptir. Ancak bazı site devletlerinde babanın otoritesine sınırlamalar da getirilmiştir. Mesela, Atina'da 18 yaşına gelen çocuklar reşit sayılarak, babanın onlar üzerindeki hayati konularda karar yetkisi kaldırılmıştır. Bazı hallerde çocuklara babalarının işlerine müdahale hakkı da tanınmıştır. Bununla birlikte babanın çocukları üzerindeki otoritesi tamamıla yok sayılmış değildir. Mesela, bir baba oğlunun artık kendi otoritesi altında bulunmadığını ve onu mirasından mahrum ettiğini ilan ettirebilmekte ve hatta aile meclisinin rızasıyla çocuğunu reddedebilmektedir. Atina'nın dışında, diğer çok bilinen site devleti Sparta'da ise evlenmek tıpkı askerlik gibi devlet görevi kabul edilmiştir. Evlilikteki amaç da devlete vatandaş yetiştirmek olarak kabul edilmiştir. Bu yüzden kocanın karısı üzerinde velayet hakkı söz konusu değildir. Çocuklar da aileye değil, devlete aittir. Diğer konularda ise babanın aile efradı üzerinde sahip olduğu konum, kendisinin fonksiyonlarını ifa edemeyecek derecede ihtiyarlaması veya ölümü halinde mevcut en büyük erkek çocuğuna devredilmektedir (Demir, 2002: 40-42).

Cermen hukukunda da baba kendi çocuğunu satabilmekte, köle olarak verebilmekte ve ölüm ile cezalandırabilmektedir. Önceleri evlilik dışı çocuklar da bir aile ferdi gibi kabul edilmiş ancak daha sonraları kilisenin etkisiyle evlilik dışı çocukların hakları oldukça zayıflatılmıştır (Demir, 2002: 42). Kilisenin etkisiyle 
zayıflayan evlilik dışı çocuk hakkına ilişkin hukuk, doğal olarak Orta Çă̆ Hıristiyanlığın içinde değerlendirilmesi gereken bir anlayışı göstermektedir. Bu haliyle de Cermen hukuku açısından biyolojik olarak bir baba olduğu kabul edilen kişinin çocuğu üzerinde tüm yaşam koşulları hakkına sahip olabildiği söylenebilir.

Yapılan araştırmalar göstermektedir ki modern çağa kadar tüm dünyada hem devlet hem de aile reisi olarak babalık otoritelerinde farklılıklar mevcut olmuştur. Ayrıca baba imajı ile devlet otoritesi arasında zaman zaman kısmi paralellikler görülmekle birlikte birçok dönemde her iki otorite tipi de aynı tarih ve coğrafya üzerinde farklı boyutlarda sürmüştür. Doğu toplumlarında en katı baba otoritesine Sümerler ve Babil dönemlerinde Mezopotamya'da şahit olunduğunda hükümdarların da Tanrı-krallık iddiasında bulunmaları her iki otorite türü arasında bir paralelliğin bulunduğunu göstermektedir. Ancak diğer Doğu toplumlarında babanın aile içinde göreli olarak daha esnek olan babalık otoritesi ile devletlerin otoriteleri arasında bir paralellik bulunduğunu söylemek çoğunlukla güçtür.

Batı toplumlarında ise tarih boyunca babalık otoritesi ile iktidar ilişkileri arasında önemli düzeyde bir benzerliğe Roma'da rastlanmaktadır. Blunt'ın ifade ettiği haliyle Antik Çă̆ Roma devletinde bir kişi, babanın mutlak sözü altında disiplinle eğitilmiş olarak yetiştirilmektedir. Aile içindeki otorite kutsal olarak kabul edilmektedir. Bu kutsallık da Romalı çocuğun büyümesiyle devlete karşı olan ödevlere aktarılmaktadır (Blunt, 1984: 74-75). Dolayısıla Roma'da babanın ve devletin otoritesinin aynı kutsallık ruhu ile desteklenmekte olduğu sonucu ortaya çıkmaktadır. Ancak zaman içinde baba otoritesinin yerine hukuki düzenlemelerin en yüksek otorite olarak devleti işaret etmesi babalık otoritesi ile devlet otoritesi arasında bir kudret ilişkisi olduğu sonucunun her zaman geçerli olmadığını göstermektedir. Zira artık baba karşısındaki evlat daha önceki dönemlere göre çok daha fazla hak sahibi olmaktadir.

Roma'da yaşanan değişim, devlete sadakatin bir yurttaşlık gereği olarak görülmesi ile uygulama alanı bulmuştur. Orta Çağ boyunca bu sadakat, feodaliteye rağmen Kilise kurumunun mutlak otorite olarak kabul edilmesinde görülür. Kilise öğretilerinin babalık otoritesini de tayin ettiği Orta Çağ' da kadınların statüsü, evlilik ve erkeklere hizmetle sınırlandırılmıştır. Orta Çağ Hıristiyanlık düşüncesinin şekillenişinde etkili olan Augustinus'a göre gerçekte ruhsal anlamda erkekler ve kadınlar aynıdır ve bu yüzden eşittir. Sorun, aralarındaki bedensel farklılıktır ve bu farklılık kadınların daha aşağı bir konumda yer almasını doğurmaktadır (Tannenbaum ve Schultz, 2008: 141-144). Çocuklara ait yaklaşım da onların yedi sekiz yaşlarından itibaren artık bir yetişkin gibi muamele görmelerinden ibarettir. Yetişkinlerin yanında, çeşitli çiftlikler de ya da uzak hanelerde çalışmak durumunda olan çocuklar o dönemde çocuk olarak görülmemektedir (Giddens, 2008: 248).

\section{Postyapısalcı Açıdan Modern Toplum, Kapitalizm ve Babalık Otoritesi}

Tarihsel süreçte mutlak monarşilerin ortaya çıkışına ait izlerden ilki Orta Çağ sonları ve Yeni Çă̆ başlarından itibaren İngiltere'de gözlenmiştir. İngiltere'nin ardından tüm Batı Avrupa'da mutlak monarşilerin yaygınlaşması sonucunda Katolik 
Hıristiyan birliği yerine bağımsız devletlerin politik hâkimiyeti başlamıştır. Mutlak monarşilerle birlikte iktidarlar, geçmişte papalığın sahip olduğu yetkileri önemli ölçüde devlet otoritesi altında kendi bünyelerinde toplamışlardır. Wallerstein'ın dediği gibi "devletler yüzyıllar boyunca bu gerçek iktidar eksikliğinin üstesinden gelmeye çalışmış ve bunu elde etmekte belirli bir başarı sağlamışlardır" (Wallerstein, 2005: 72). Feodal beyliklerin otoritelerini de zamanla kontrol altına alan mutlak monarşiler artık hem geçmişteki Katolik Kilisenin tüm Hıristiyanları kapsayan otoritesini, hem de feodaliteye özgü yerel seçkinlerin otoritesini bir merkezde toplamaya başlamıştır. Bu gelişmeler, doğal olarak Orta Çağ'da babalık otoritesini belirlemekte olan Kilise kurumunun yetkisini de mutlak monarşik krallıkların devralmasını sağlamıştır.

Öte yandan bu dönemde ilk kapitalist girişimciler aracılığıyla Batı Avrupa'da sermaye birikimi oluşmaya başlamıştır. Sermayeyi kontrol eden kapitalizmle mutlak monarşiler arasındaki sıkı bağ büyük bir sistemin doğuşunu belirlemiştir. Yeni bir ekonomik şekillenmenin ortasındaki kitleler için daha organize olmuş bir biçimdeki kapitalist ekonomiyle uygun düşen çalışma şartları bir hayat tarzı olarak tek seçenek haline gelmiştir. Kapitalist yapılanma sonucunda ailelerde bir değişme ortaya çıkmıştır. Giddens'a göre 17. yüzyıldan itibaren akrabalarla derin bağlılık içindeki yapı dağılmış ve yakın duygusal bağlarla örülü, ev mahremiyetinin yüksek düzeyde olduğu ve çocukların yetiştirilmesini uğraş edinen bir topluluk olarak yeni aile tipi ortaya çıkmıştır. Ancak bu değişme sanılanın aksine geniş aileden çekirdek aileye dönüşme şeklinde vuku bulmamıştır. Zira modern öncesi dönemde Batı Avrupa'da geniş aile tipinin bulunduğuna ilişkin düşünce yanlıştır. Geçmişte de baba, anne ve çocuklardan oluşan aile tipi, en yaygın olandır. Ancak, modern öncesi döneme özgü çekirdek aile, başka akrabalarla olan ilişkilerini birbirlerine derin bağlılık duyarak yürütmektedir. İşte değişim göstermeye başlamış olan, akrabalık bağının kuvvetli olduğu bu aile tipidir (Giddens, 2008: 248-249). Değişme sonucunda yakın akrabalarla bağını minimize eden yeni aile tipi kendi dönemine özgü sanayileşme-şehirleşme ilişkileri ile uyumlu bir topluluk örneğini meydana getirmiştir. Böylece çekirdek aile, artık başlı başına toplumun temel direği sayılan bir kurum olarak ortaya çıkmıştır.

Ailenin yeni sistemin temelinde yer alması birçok düşünür tarafından daima kapitalist işletimin bir gerekliliği olarak gösterilmektedir. Sözgelimi Deleuze ve Guattari'ye göre kapitalizm, modern toplumsallık yapısında devletleri, vatanları ve aileleri kendine özgü yapısıyla kodlamakta ve biçimlendirmektedir (Deleuze ve Guattari, 2014a: 57-58). Oysa daha önceki toplumsallık biçimlerinde aile ile toplumsal saha arasında karşılıklı bir bağ ve uyum vardır (Deleuze ve Guattari 2014a: 381). Kapitalist pazar içinde aile tamamiyla alt bir konuma indirilmiştir (Holland, 2013: 155). Böylece aile artık hâkim olmadığı şeyi ifade etmek için uygun kılınmış bir mikrokozmosa dönüştürülmüştür (Deleuze ve Guattari 2014a: 383). Demek oluyor ki Deleuze ve Guattari için kapitalizm, aile üzerinden bireyleri bir sisteme dâhil etmektedir. Onların gözünde modern çekirdek aile, itaatkâr kültür alanı oluşturan kapitalizmin altındaki bir temsil alanını oluşturmaktadır.

Gerçekte modern çağ içinde yükselerek gelişen kapitalist yapıya özgü iktidar eleştirileri 19. yüzyılda belirginleşmeye başlamıştır. Düşünsel alanda Marx, bu eleştirel 
biçimin merkezinde yer alır ve yüksek bir etki düzeyi yakalar. Toplumsal alanda ise oluşan yeni gruplara özgü hareketler bir başka karşı duruşu temsil etmektedir. İktidar eleştirilerinin hem düşünce hem de toplumsal eylemler düzeyinde hızla yayılmasını sağlayan da aslında Batı kapitalizminin ve sömürge faaliyetlerinin kendisi olmuştur. Zira 19. yüzyıl boyunca Batı Avrupa, sadece toprak bakımından değil bir düşünce biçimi haliyle dünyanın çok büyük çoğunluğunu fethetmiştir.

Dünyanın neresinde olursa olsun modernliğin girdiği her yerde iş̧̧i hareketleri, feminist hareketler ve çevreci hareketler gibi toplumsal grupların etkinliği gözlenir olmuştur. Bu bölgelerde çalışanlar, işgal altındakiler, kadınlar, çeşitli türden azınlıklar kendilerine bir öznellik yaratmışlardır (Touraine, 2007: 121). Öznellik bilinci sadece ikincil düzeyde kalmış olanlara özgü değildir elbette. Gittikçe artan bir oranda bireyler, modern düşünce ile barışık olan bu öznelliğin içinde kendilerini şekillendirmişlerdir.

Yeni öznellik alanının aile ilişkilerine etkisi, erkek ve kadının birbirlerine karşı yaklaşımlarında olduğu kadar aile içindeki konumlarında da değişmeye yol açmıştır. Çünkü artık evlilikler de karşılıklı tutkuların bir ürünü olarak gerçekleşme eğilimine girmiştir. Hatta aileye ilişkin bu tutkulu bağlılığın ebediyen sürmesi umudu, Carpenter'ın da belirttiği gibi romantik edebiyatın esas teması olmuş ve binlerce romanda ve şiirde zirve noktasına ulaşmıştır (Carpenter, 2008: 101). İşte erkek ve kadın arasındaki göreli eşitliği başlatan romantik yaklaşım aslında kendi çağında bireyin modern öznellik içindeki aidiyet, sadakat ve varlık alanının temsili olmaktadır. Artık birey sadece hükümdarlar ya da Kilise kurumlarının bir ferdi değil aynı zamanda kendine ait kurduğu bir alanda karar alma süreçlerini harekete geçiren bir eylemcidir.

Yeni öznellik alanının aktörlerinin eşitliği aynı zamanda toplumsal eşitliğin de bir uzantısıdır. Foucault bu durumu, iktidarın ancak özgür bireylerin varlığı üzerine uygulanabileceğini söyleyerek belirtmektedir. Ona göre tamamen belirlenmiş ilişkiler bir iktidar ilişkisi olamaz. Kölelerin zincirleri ile yaşamaları bir iktidar ilişkisi değildir (Foucault, 1982: 790). Çünkü Foucault'ya göre ancak özgürlük alanının mevcudiyeti ile birlikte yöneten yönetilen ilişkisi iradi bir karar almanın ve uygulamanın karmaşıklı̆̆ını doğurabilmektedir.

Yeni öznellik alanının aktörlerinin varlıklarını gösterme amacıyla öne çıktığı en dikkat çekici gelişme Avrupa'da 1848 yılından itibaren görülen sistem karşıtı hareketlerdir Sistem karşıtı hareketler öncelikle, diğer toplumsal hareketlerden farklı olarak uluslararası sisteme yönelik protestoları içerir. Fakat aynı zamanda kadın hakları hareketinin başlamasına ve bir bilinç dönüşümünün yaşanmasına da yol açmıştır. Zira 1848, yaklaşık on yıl boyunca büyüyen bir radikal uluslararası feminist hareketi de kucaklamıştır (Martin, 2008: 95). Dolayısıyla sistem karşıtı hareketlerin başlangıcı bir yandan otoriter yapıya karşı duruşu gösterirken bir yandan da feminist eylemler yoluyla erkek egemen ilişkilerin toplumda sorgulanmasına yönelik adımların atılmasını doğurmuştur. Böylece görece eşit konuma vurgu yapan kadınların hem sistem, hem de aile reisliği ile örtüşen babalık otoritesine itirazı dile getirilmiş olunmaktadır. Bu itiraz ile aslında çekirdek aile ile kapitalist sistem arasında kurulan makro ve mikro ölçekli bağların toplumda karşılığını bulduğu anlaşılmaktadır. Zira 
mevcut aile yapısına ve kapitalizmin uluslararası sistemine aynı anda tepki verilmiştir. Böylece modern toplumsal düzene karşı duruş, ataerkilliğe de bir karşı duruşu doğal olarak ortaya çıkarmıştır.

Entelektüel düzeyde iktidarlara karşı yöneltilen eleştiriler ve tutumlar ise 19 . yüzyıl boyunca sosyalist düşünce etrafında şekillenmeye başlamıştır. Fakat modern devletlerin iktidar yapısına karşı asıl kapsamlı eleştiri 20. yüzyılın ilk çeyreğinden itibaren Marksizmin yeniden yorumlanmasıyla ortaya çıkmıştır. Gramsci'den itibaren başlayan bu eleştiri, Frankfurt Okulu mensupları tarafından Marksizmin, altyapıdan ziyade üstyapının konusu olarak ele alınmasıyla kendine farklı bir yol çizmiştir. İktidar ilişkilerini bir yapının biçimi ile açıklayan yapısalcılar modern çă̆ ile birlikte iktidarların ve kapitalist yapılanmanın artık her şeyi kontrol ettiğini söylemektedirler.

Marksizmin yeniden yorumlanışı yoluyla ulaşılan bu yeni yaklaşımlar merkezi iktidarlara ve tüm otoriter yapılara karşı yeni bir eleştirel geleneğin doğmasını sağlamışlardır. Althusser'le birlikte zirve noktasına ulaşan yapısalcı eleştiri 1960'lardan itibaren yerini postyapısalcı eleştiriye bırakmaya başlamıştır. Postyapısalcılar'ı yapısalcılardan farklı kılan şey ise özetle, yapısalcıların, öznenin, iktidarlar aracılığı ile bir yapının içinde edilgen hale geldiğini iddia etmelerine ilave olarak postyapısalcıların mevcut yapılanmanın öznenin özüne aykırı olduğunu söyleyerek yapıyı kırmaya çalışmalarıdır. Postyapısalcı yaklaşımların iktidarlara yönelik eleştirilerindeki hedeflerinde baba devlet imajı önemli bir yer tutmaktadır. Bu durum, aile içindeki babanın erkek egemenliğini de kapsayan geniş çaplı bir sorgulayıcılığı doğurmuştur.

Merkezi iktidar politikasını hedefine alan postyapısalcı eleştiri, tıpkı yapısalcılıktaki gibi modern toplumsal sistemin gerçekçi bir zemine dayanmayan inşa ürünü homojen toplum tipini ürettiği fikri etrafında kümelenmektedir. Buradan hareketle postyapısalcılık, homojen toplum düşüncesinin sorgulanmasına özel bir önem vererek mevcut yapıyı kabul etmemekte ve bu yapının çoğulculuk lehine bozulması gerektiğini savunmaktadır. Devamla da babalığa ve ataerkilliğe ait her türlü olumlu yaklaşımın da dağıtılmasını istemektedir.

Kaldı ki Foucault, iktidar ilişkilerinin sosyal bağın derinliklerinde kök salmış olduğunu öne sürmektedir. Ona göre her durumda bir toplum içinde yaşamak bir eylemin başka bir eylem üzerine devamı ile oluşmaktadır. İktidar ilişkileri bu yüzden farklılıklara, bir hedefe, araçlara, kurumsallaşmaya ve rasyonelleşmeye ihtiyaç duymaktadır (Foucault, 1982: 791-792). Aslında bu sosyal bağın derinlikleri Foucault'nun terimiyle 'söylem'dir. Ona göre söylem, hem özneleri hem de nesneleri yaratan, düzenlenmiş bir sosyal pratiktir. İşte böyle belirli bir söylem çerçevesi içinde bilgi de, iktidar da oluşturulmaktadır (Hekman, 1999: 226-227.) Foucault açısından, bu söylem alanında artık özne kurucu olmaktan çok kurulandır (May, 2000: 98). Bu durumda da özne, toplumsal etkileşimlerden ve derin bağlardan oluşmuş iktidar ilişkilerinin sistemi içinde beliren bir varlığa dönüşmektedir. Yani özne, çerçevesi sınırlanmış bir öznellik alanın aktörü haline gelmektedir. $\mathrm{O}$ artık Foucault için pasif bir kurulandir. 
Bir başka postyapısalcı Deleuze ve çalışma arkadaşı Guattari de öznenin kapitalist sistem içinde bir kurulan durumuna düştüğünü öne sürmektedir. Onlara göre iki tür topluluk mevcuttur. Bunların biri büyük toplanışlardır diğeri ise mikroçokluklardır. Birincisi, itaat ettiren hâkimiyet biçimindeki sürüsel toplanışlara özgü, tabi olan grup tipidir. İkincisi ise yanal çokluklar içinde özgür akımlar olarak bulunan özne oluşların grubudur (Deleuze ve Guattari, 2014a: 403-404). Bu iki kutuptan birincisinde büyük toplanışlar, yani sürüselliğin büyük biçimleri bulunmaktadır. Ama diğer kutupta toplumsalı kemiren ve onu yarıp geçen, devrimci bir güce dönüşümü sağlayan çokluklar yer almaktadır (Deleuze ve Guattari, 2014a: 490). İki grup arasındaki fark birincideki öznenin pasif ve dolayısıyla kurulan öznellik alanına ait oluşu iken ikincisinin kendi gerçekliğini sağlayan özgür özne oluşa ait gruptur. Burada, iki grup arasındaki ayrımın hem Althusser'de hem de Nietzshe'de ifade edilmiş olduğunu vurgulamakta fayda vardır.

Deleuze ve Guattari'ye göre her şey politiktir. Onlara göre bu politiklik iki ana kulvara sahiptir. Çünkü her politik olan aynı zamanda makropolitik ve mikropolitiktir. Ancak alg1 ve hissediş tipinin biraradalığı olarak molar sürüsel organizasyon, yani makropolitik yapı mikroalgıların dünyasını engellememektedir (Deleuze ve Guattari, 2014b: 249). Mikropolitik alan sabit bir yapı gibi değil, bir rizom biçiminde işlemektedir. Rizomun temel karakteristiği ise bir noktayı diğer noktaya bağlamakta olduğudur. Ne başlangıca, ne de sona sahiptir. O bütünlüklerden değil hareket halindeki yönlerden oluşmuştur. $\mathrm{O}$, öznesi ve nesnesi olmayan $n$ boyutlu çokluğa sahiptir. Bu bakımdan rizom, merkezsiz, hiyerarşisiz bir sistemdir (Deleuze ve Guattari, 2014b: 21-22). Başka bir ifade ile rizom çoklu bağlantı içinde olmaktır.

Foucault'ya benzer şekilde Deleuze ve Guattari, toplumsal alanı hiyerarşik ilişkiler bütünü olarak görür ve eleştirir. Fakat Foucault'dan farklı olarak toplumu bir ağ olarak ele alınması gerektiği fikrini savunurlar (May, 2000: 105). Bir ağ olan topluluk tipinde merkez de bulunmadığ için merkeze karşılık gelecek ya da onu temsil edecek bir otoritenin de bulunmaması gerekmektedir. Böylece hiyerarşik ilişkilerin varlığı da lüzumsuz hale gelecektir. Bu yaklaşım biçimi tam anlamıla yazılı tarih içinde bilinen otorite anlayışının tersyüz edilmesi anlamına gelmektedir. İşte bir başka postyapısalcı düşünür Derrida'nın da geliştirdiği yapısökümü kavramı zaten mevcut yapıyı tersyüz edip çokluk lehine yorumlamaktır.

Derrida'ya göre yapısökümü, kuşkuculuk ya da tahrip etme değil, bir metnin içindeki anlamları didiklemektir. Yapısökümünün başlıca argümanlarından biri, yorumun bir üretim türü olduğudur. Metnin 'doğru' anlamını bulma ya da yazarın niyetini keşfetme girişimi değil, daha çok, yorumu, kendi içinde bir ürün yaratma eylemidir (Hekman, 1999: 248-249). Derrida'nın geliştirdiği yapısökümü ile yapısalcı eleştiri tam anlamıyla aşılmış olunmaktadır. Zira yapısalcılığın temelinde yer alan yapının özneyi ve ilişkileri belirlediği fikri yerine öznenin yorumlama gücü ile metnin anlamı çoğaltılmakta ve metin bir sabitlik alanının dışına çıkarılmaktadır. Dolayısıyla artık değişmez olan ve tek anlam taşıyan yapı özgürlüğe açılmakta ve çoklu bağlantılara taşınmaktadır. 


\section{SONUÇ}

Postyapısalcılar genel itibarla kapitalizm eleştirisi yapmış olsalar da onlar için asıl sorun Platon'dan beri devam eden temsilci ve hiyerarşik olan idealist düşünce sisteminin egemenliğidir. Çünkü onlara göre Antik Çağdan bu yana bu düşünce sistemi içinde oluşan bilgi ve siyaset birikiminin hümanizma ile birleşmesi sonucunda modern kapitalist iktidar biçiminin otoriterliği doğmuştur. Babalık otoritesi de kapitalizmin egemenliğindeki bu temsilci ve hiyerarşik yapıda bir alt birim haline gelmiştir.

Oysa çağdaş Batı tipi yurttaşlık ilişkilerindeki otoriterlik örneğini sadece idealist felsefeye değil Antik Roma'ya dayandırmak da mümkündür. Öte yandan Sparta örneğinde olduğu gibi devlet otoritesinin tüm yurttaşların üstünde tutulduğu bir anlayışın Batı toplum yapısındaki varlığı tamamıyla idealist felsefe dışında gerçekleşmiştir. Her ne kadar son dönem otoriter yönetim tarzları ile idealizm arasında bir bağ kuruluyor olsa da Sparta site devletinin idealist felsefeden beslenerek yapılandığını söylemek mümkün değildir.

$\mathrm{Bu}$ durumda hem Foucault, hem Deleuze ve Guattari hem de Derrida'nın Platon'a karşı duruşlarının nedeninin bir otoriter düşünce sistemi ve toplum yapısını üretmek olduğunu söylemek güçleşmektedir. Oysa bu düşünürler Platonculuğun düşünce tarihinde hem bir otoriteye dönüştüğ̈̈nü hem de gelişen çeşitli otoritelerin zemininde yer aldığını öne sürmektedirler. Bu Platoncu otoritenin, Foucault'da hakkikat rejimi, Deleuze'de temsilci aşkınlık Derrida'da mevcudiyet metafiziği olarak adlandırıldığı görülmektedir (Hekman, 1999: 237-245; Deleuze, 2015: 279-285). Fakat eğer postyapısalcıların iddiaları doğru kabul edilirse bu durumda otoriteyi sağlayan düşüncenin Platon'dan kaynaklanması gerekmektedir. Oysa her türlü otoritenin dünya üzerindeki varlığına Platondan binlerce yıl öncesinden şahit olunmaktadır. Platoncu düşünce geleneğinin iktidar ilişkilerine ait yapıyı etkilemiş olması kuvvetle muhtemel olmakla birlikte Platon öncesinde merkezi iktidarların kudretlerine bakıldığında otoriterlik ve tek merkezlilik üzerinden yapının eleştirisini Platon'a bağlamak yetersiz kalmaktadir.

Öte yandan bizatihi yapısalcı ve postyapısalcı yaklaşımların iktidar eleştirilerinin haklılığı durumunda bile, bir başına yapının olumsuz olduğu anlamı ortaya çıkmaz. Zira Poppercu bir bakış açısıyla söylenecek olursa tek tek yapısal örneklerin analizinin tamamının yanlışlığını gösterecek bir bilgi birikimine ulaşmak mümkün olmadığı gibi ulaşılsa dahi bu, sonraki herhangi bir yapının da yanlış olacağını ispatlamaz.

Son olarak da postyapısalcı düşünürlerin çokluk lehine olarak yapıya, birliğe ve merkeziliğe ilişkin eleştirileri gerçekte çokluğu ya da herhangi birçoklu yaklaşımı da ortaya koymamaktadır. Çünkü postyapısalcı düşünürler her ne kadar genel geçer bir sistem dışında yöntemsiz olarak çokluğu savunmakta olduklarını iddia etseler de öne sürdükleri yaklaşım modelleri bizzat bir yöntem olarak varlık kazanmaktadır. Onlar, farklı ve yeni bir yaklaşımı, bir başka yöntem olarak önermektedirler. Bu durumda bu 
yeni yöntem, yapılacak olan analiz ve yorumlamalar için bir otorite haline gelmektedir. Zira başkaca bir yöntemi doğru olarak görmemektedir. Bu, başlı başına bir çelişkidir.

Bununla birlikte yaşanan gelişmelere bakıldığında postyapısalcı eleştirel yaklaşım içinde aile otoritesi de dâhil her otorite, öznenin merkez tanımadan kendi bağlantıları etrafındaki çoklu ilişkiler ağı içinde eritilmektedir. Postyapısalcı eleştirilerin yapıyı tersyüz eden yaklaşımlarına paralel olarak günümüz aile tarzında ataerkil düşünce biçiminin de tersyüz edildiği görülmektedir. Kaldı ki aile reisliği kavramının günümüzde hukuki bakımdan eşitlik karşıtı bir ifadeyi içeriyor olarak değerlendirilmesi bu gerçekliği açıkça ortaya koymaktadır. Dolayısıyla mevcut tartışma, sorunun erkek ve kadın arasındaki iktidarı ele geçirme mücadelesinden ziyade iktidar oluşturacak bir gücün ortadan kalkması için verilen bir çabayı göstermektedir. Dahası, çoksesliliği isteyen ve merkezi iktidar yapısını güçlerinden dolayı eleştiren sözde otorite karşıtı bir yaklaşımın otorite olma isteğine şahit olunmaktadir.

\section{KAYNAKÇA}

Aksoy, İ. (2011). Türklerde Aile ve Çocuk Eğitimi, Uluslararası Sosyal Araştırmalar Dergisi, 16 (4): 11-19.

Berki, Ş. (1957). Roma'da Aile Hukuku, Ankara Üniversitesi Hukuk Fakültesi Dergisi, 14: 111-121.

Blunt, A. W. F. (1984). Batı Uygarlı̆̆ııı Temelleri (M. Erim Çev.). İstanbul: İstanbul Üniversitesi Edebiyat Fakültesi Yay.

Bozkurt, G. (1981). Eski Hukuk Sistemlerinde Kölelik, Ankara Üniversitesi Hukuk Fakültesi Dergisi, 38: 65-103.

Carpenter, E. (208). Batı Uygarlı̆̆ının Krizi (O. Düz Çev.). İstanbul: Külliyat Yayınları.

Deleuze, G. (2015) Anlamın Mantı̆̆̊ (H. Yücefer Çev.). İstanbul: Norgunk Yayıncılık.

Deleuze G. ve Guattari F. (2014a) Anti-Ödipus Kapitalizm ve Şizofreni 1 (F. Ege v.d. Çev.). Ankara: Bilim ve Sosyalizm Yayınları.

Deleuze G. and Guattari F. (2014b) A Thousand Plateaus (B. Massumi Trans.). London: Bloomsbury Publishing Plc.

Demir, A. (2012). Tarihten Günümüze Çocuk Hakları, International Journal of Early Chidhood Education Research, 3 (1): 37-47.

Foucault, M. (1982). The Subject and Power, Critical Inquiry, 4 (8): 777-795.

Giddens, A. (2008). Sosyoloji (H. Özel v.d. Çev.). İstanbul: Kırmızı Yayınları.

Hekman, S. (1999). Bilgi Sosyolojisi ve Hermeneutik (H. Arslan ve B. Balkız Çev.). İstanbul: Paradigma Yayınları.

Holland, W. H. (2013) Deleuze ve Guattari'nin Anti-Oedipus'u Şizoanalize Giriş (A. Utku ve M. Erkan Çev.). İstanbul: Otonom Yayıncılık.

Martin, W. G. (2008) Toplumsal Hareketler 1750-2005 (D. Keskin Çev.) İstanbul: Versus Kitap.

May, T. (2000) Postyapısalcı Anarşizmin Siyaset Felsefesi (Rahmi G. Ö. Çev.). İstanbul: Ayrıntı Yayınları. 
Öke, M. K. (2010) Kaderle Dans: Özgürlük-Güvenlik Kıskacındaki Latin Amerika'da Kimlik Sorunsalı, İstanbul: Başlık Yayın Grubu.

Tannenbaum, D. ve G. - Schultz, D. (2008) Siyasi Düşünce Tarihi, (F. Demirci Çev.). Ankara: Adres Yayınları.

Touraine, A. (2007) Yeni Bir Paradigma, (O. Kunal Çev.). İstanbul: Yapı Kredi Yayınları.

Wallerstein, I. (2005) Dünya Sistemleri Analizi, (E. Abadaoğlu ve N. Ersoy Çev.). İstanbul: Aram Yayınları.

Yalvaç, K. (1965) Eski Babil'de Kız Evladın Miras Meselesi, Ankara Üniversitesi Dil ve TarihCoğrafya Fakültesi Dergisi, 1 ve 2 (23): 31-36. 